\title{
MONITORING A THERMOPHILOUS WOODLAND REFORESTATION PROJECT IN TENERIFE, CANARY ISLANDS
}

\author{
Francesco Rota*, Mercedes Vidal-Rodríguez ${ }^{* *}$, Alessandro Chiarucci ${ }^{* * *}$, \\ José María Fernández-Palacios ${ }^{* *}$, Robert J. Whittaker
}

Abstract

The Canarian juniper woodland, dominated by Juniperus turbinata ssp. canariensis, is a priority habitat and is among the most endangered ecosystems of the European Union. Saplings of 12 species were planted between March 2006 and January 2008 within the Rural Park of Teno (Tenerife) during a LIFE reforestation project. To assess the replanting effectiveness, six $25 \times 25$ m permanent plots were established for monitoring plant conditions in 2014. We report the results of annual surveys up to 2019. We recorded vitality, phenology and size of 225 planted individuals belonging to eight different species. The vitality showed general positive trends, with a low 2018 decrease. Around $30 \%$ of surviving saplings displayed flowers or fruits in 2019. Juniperus turbinata ssp. canariensis and Olea cerasiformis presented a significant increment for all the growth traits, but only the juniper showed locally varied patterns of growth. We expect that the monitoring will contribute useful insights for other restoration projects for the endangered Canary endemic thermophilous woodland.

KEYWORDS: ecological monitoring, endemic juniper woodland, functional traits, restoration ecology, Tenerife.

\author{
SEGUIMIENTO DE UN PROYECTO DE REFORESTACIÓN \\ DEL BOSQUE TERMÓFILO EN TENERIFE, ISLAS CANARIAS
}

\section{RESUMEN}

El sabinar, comunidad dominada por Juniperus turbinata ssp. canariensis, constituye un hábitat prioritario de la Unión Europea. En el marco de un proyecto LIFE de reforestación entre marzo de 2006 y enero de 2008 fueron plantadas plántulas de 12 especies leñosas en el Parque Rural de Teno (Tenerife). Para comprobar el éxito de la plantación se establecieron en el año 2014 seis parcelas permanentes cuadradas de $25 \mathrm{~m}$ de lado en la zona reforestada. En este trabajo se describen los resultados del seguimiento anual llevado a cabo hasta 2019. Se registraron valores de vitalidad, fenología y tamaño de 225 individuos pertenecientes a ocho especies diferentes. La vitalidad presenta una tendencia positiva, con un pequeño bajón en 2018, mientras que el 30\% de los individuos supervivientes ya producían flores o frutos en 2019. Juniperus turbinata ssp. canariensis y Olea cerasiformis presentaron un incremento significativo para todos los rasgos analizados, pero solo la sabina mostró patrones de crecimiento localmente variados. Esperamos que el seguimiento contribuya con conocimientos útiles para otros proyectos de restauración del amenazado bosque termófilo endémico canario.

KEYWORDs: seguimiento ecológico, bosque de cedros endémicos, rasgos funcionales, ecología de la restauración, Tenerife.

DOI: https://doi.org/10.25145/j.SI.2021.04.02

Revista Scientia Insularum, 4; diciembre 2021, pp. 27-43; ISSN: e-2659-6644 


\section{INTRODUCTION}

The thermophilous woodland in the Canaries is a highly degraded and threatened ecosystem, owing to its occurrence within the most valuable agricultural areas of the islands (mid-elevation - medianias - of both windward and leeward slopes) and today due to the closeness of the few remnant juniper patches to areas with intensive human activities, such as urbanizations or infrastructure constructions (Fernández Palacios et al. 2008). On Tenerife, the remaining remnants, are few, small and scattered, mostly being restricted to inaccessible gullies and slopes (Otto et al.2012, Fernández-Palacios et al. 2020) (figures 1, 2). An endemic juniper restoration project (LIFE04/NAT/ES/000064) was developed by the island government (Cabildo Insular de Tenerife) and funded in part by the Cabildo, but especially with funds from the European Union. The restoration was implemented within the Teno Rural Park, in the north-west of Tenerife, during 2005-2008. The goal of this project was to trial the restoration of the juniper community in Tenerife by planting Juniperus turbinata ssp. canariensis (Guyot and Mathou) Rivas Mart., Wildpret and P. Pérez and other key species of this formation, such as the endemic wild olive (Olea cerasiformis Rivas Mart. and del Arco). The other species included in the planting were Euphorbia atropurpurea Broussonet, Globularia salicina Lam., Gymnosporia cassinoides (L'Hér.) Masf., Hypericum canariense L., Jasminum odoratissimum L., Pistacia atlantica Desf., Retama rhodorhizoides (Webb and Berthel.) Webb and Berthel., Rhamnus crenulata Aiton, the thermophilous ecotype of Heberdenia excelsa (Ait.) Banks and Visnea mocanera L.f. (Fernández-Palacios et al. 2008). A second goal was to contribute to the scientific knowledge about the ecology of these species and the dynamics of this plant community (e.g. see Otto et al. 2010). A third goal was to gain experience restoring this ecosystem within a protected area such as a Rural Park, sharing this knowledge with local people in order to show how the thermophilous woodland restoration can be compatible with the conservation of traditional rural activities (Fernández-Palacios et al. 2008). Even if project-level monitoring has historically been neglected, it is a necessary component of forest restorations (Schultz et al. 2012). The present work aims to provide quantitative data on the early years of the Teno thermophilous woodland restoration project.

The initial plantation density in 2006-2008 was of c. 1237 plants hectare ${ }^{-1}$ (Fernández-Palacios et al. 2008). There were early indications of inter-specific variation in performance in the plantation, showing differential responses to seasonal

* Faculty of Science and Technology, Free University of Bozen/Bolzano, Bozen/Bolzano, Italy.E-mail: francesco.rota@natec.unibz.it.

** Grupo de Investigación Interuniversitario de Ecología y Biogeografía Insular, Universidad de La Laguna, San Cristóbal de la Laguna, Tenerife, Canary Islands, Spain

*** Biodiversity and Macroecology (BIOME) Research Group, Department of Biological, Geological and Environmental Sciences, Alma Mater Studiorum - University of Bologna, Bologna, Italy.

- School of Geography and the Environment, University of Oxford, Oxford, UK. 


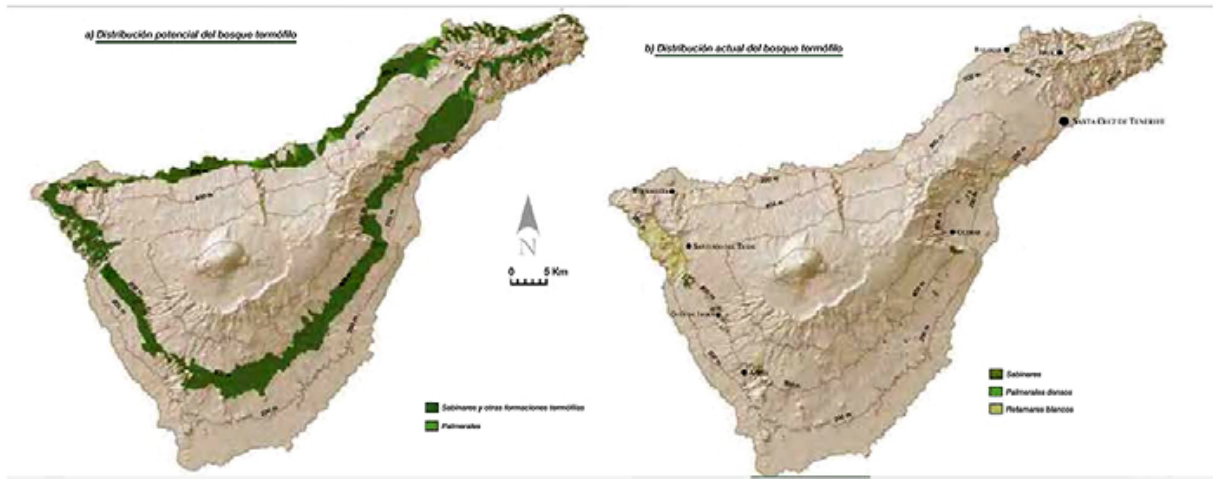

Figure 1. The pre-human (left) and current (right) distribution of thermophilous woodlands on Tenerife (from Fernández-Palacios et al. 2008, based on del Arco et al. 2006).

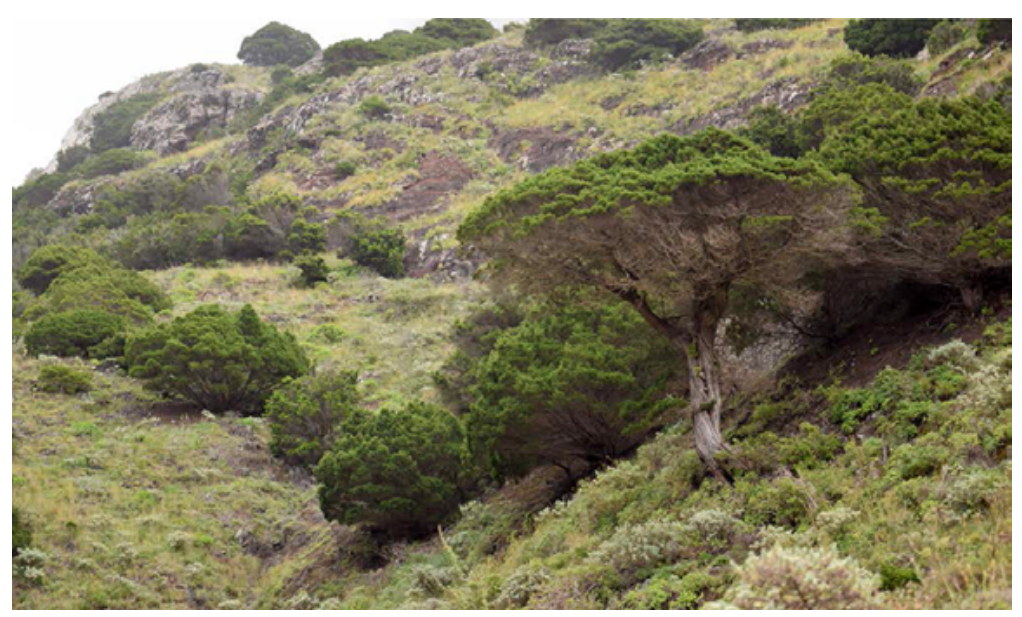

Figure 2. One of the remnants of the Juniper community in Afur, Tenerife.

(Photo Francesco Rota).

adverse weather conditions, late planting date and/or herbivory, especially after the removal of the metal grid protectors initially used to protect the saplings against rabbits and goats (Fernández-Palacios et al. 2008). However, for several years after 2008, no monitoring was carried out. In March 2014 a monitoring effort was initiated, to record the regrowth by establishing permanent plots in the upper part of the estate (700-850 $\mathrm{m}$ a.s.l.). The field data collection was carried out together by the MSc Biodiversity, Conservation and Management (University of Oxford) 
and the MSc "Biodiversidad Terrestre y Conservación en Islas" (University of La Laguna) field-course students and professors, as an instructive exercise for them and to generate the data reported herein. On each occasion, the data has been recorded in a single afternoon and by students who have no prior experience of the site, but under supervision of the same experienced staff. The principal goal was to record the survival and growth of the saplings planted and to continue monitoring the sites as the woodland cover develops.

\section{MATERIAL AND METHODS}

\section{STUdy SPECIES}

The species selected in any restoration project depend on the community to be restored. In this case it was a dry juniper community for the lower part, with a transition community towards a humid juniper woodland in the upper part of the site, more favoured by the overflowing sea of clouds, that is formed by the northeastern humid winds. The high abundance of Juniperus turbinata ssp. canariensis and Olea cerasiformis, still existing in inaccessible cliffs of the few remnants of thermophilous woodland belt on Tenerife, justifies their selection as structural species in the restoration. Moreover, several place names of the surroundings indicate a putative historical presence of junipers (e.g. "El Sabinal", used for an area of the restoration land, from Spanish "sabina" = juniper) (Fernández-Palacios et al. 2008). There are no appropriate sedimentary sites in the zone (lakes, calderas, etc.) for carrying out a palaeoecological analysis that could confirm the composition of the woodland cover prior to human arrival. Juniperus and Olea improve the structure and composition diversity, since they show a certain 'nurse' effect, mitigating the adverse environmental conditions of the zone, decreasing the wind speed, increasing the humidity and shade of the site (Fernández-Palacios et al. 2008, Otto et al. 2010). Following the natural pattern, a series of auxiliary species were chosen for the plantation. Globularia salicina, Euphorbia atropurpurea and Retama rhodorhizoides were used in lower areas of the site, but not in the upper part of the restoration zone where the monitoring plots are. Therefore, restoration monitoring included data for two structural species, Juniperus turbinata ssp. canariensis and Olea cerasiformis, and six auxiliary woody species: Gymnosporia cassinoides, Heberdenia excelsa, Hypericum canariense, Jasminum odoratissimum, Pistacia atlantica and Visnea mocanera.

\section{The JUNiPer COMmUNity AND THE TAXONOMIC STATUS OF THE “SABINA"}

The Juniper woodland, also called sabinar, is a community dominated by Juniperus turbinata ssp. canariensis in its mature state (figure. 2). Due to its elevational distribution, between 200 and $400 \mathrm{~m}$ a.s.l. on windward slopes and between 400 and $800 \mathrm{~m}$ a.s.l. on leeward slopes, we can distinguish two types of juniper communities. (1) The humid sabinar, in the northern or eastern windward slopes, 
experiences lower temperatures, reduced actual evapotranspiration and slightly higher precipitation $(300-450 \mathrm{~mm} /$ year) due to the influence of the sea of clouds (Fernández-Palacios et al. 2008). (2) The dry sabinar, located in the southern and western leeward slopes, experiences rainfall of about 200-300 mm/year, higher levels of actual evapotranspiration and higher temperatures. According to the requirements of each species, there are compositional differences in response to these environmental differences (Otto et al. 2012). The species favouring the windward sites, such as Argyranthemum spp., Echium strictum, Erica arborea, Erysimum bicolor, Heberdenia excelsa, Hypericum canariense, Marcetella moquiniana, Morella faya, Pericallis spp., Sideroxylon canariensis, Sonchus spp. and Visnea mocanera require wetter conditions. Within the drier sites, the thermophilous elements adapted to a moderate hydric stress predominate, such as Bupleurum salicifolium, Carlina salicifolia, C. canariensis, Cistus monspeliensis, C. symphytifolius, Convolvulus floridus, Echium aculeatum, Globularia salicina, Jasminum odoratissimum, Olea cerasiformis, Pistacia atlantica, Retama rhodorhizoides and Rhamnus crenulata. These juniper communities do not require particularly rich soils, and depending on the elevation and the exposure to the trade winds, they can grow in more or less stony soils (Bello-Rodríguez et al. 2016).

The genus Juniperus (Cupressaceae) includes more than 67 species distributed all over the North Hemisphere (Adams, 2006). Juniperus turbinata ssp. canariensis is an endemic monoecious tree of the Canaries and Madeira and its taxonomic status is still a topic of discussion, with genetic values and morphological characters supporting the recognition of the Canary Island juniper of the phoenicea group at a specific level as J. canariensis Guyot in Mathou and Guyot (Romo et al. 2019). This species occurs nowadays in the central and western Canary Islands, as well as in Madeira and Porto Santo. It may also have occurred on Lanzarote and Fuerteventura prior to the anthropogenic transformation of these islands (del Arco et al. 2016). Although juniper woodland is considered the most extended thermophilous community on the western Canary Islands, today it is only well-preserved on El Hierro and La Gomera (von Gaisberg, 2005), and it appears very fragmented in La Palma, Tenerife and Gran Canaria (Fernández-Palacios et al. 2020, del Arco et al. 2010). The reddish brown fleshy-fruits (cones) of the juniper contain 3-7 seeds and they are mainly dispersed by lizards (Gallotia spp.) and, to a lesser extent but potentially further, by frugivorous birds, such as the blackbird (Turdus merula cabrerae) and the locally threatened raven (Corvus corax canariensis). The seeds are also predated by the brown rat (Rattus rattus) and the rabbit (Oryctolagus cuniculus), both species introduced by the Castilians in the $\mathrm{xV}$ century. J. turbinata ssp. canariensis regeneration typically displays a very slow progress because of the hydric stress causing problems in seedlings germination and establishment (Otto et al. 2006; 2010). The species shows a $K$-strategy, typical of dominant species of late successional stages. Thus, this species presents a particular challenge for ecological recovery and/or restoration, because of the long time needed for its growth. For these reasons, the presence and abundance of $J$. turbinata ssp. canariensis are good indicators of the state of the community (Fernández-Palacios et al. 2008). 

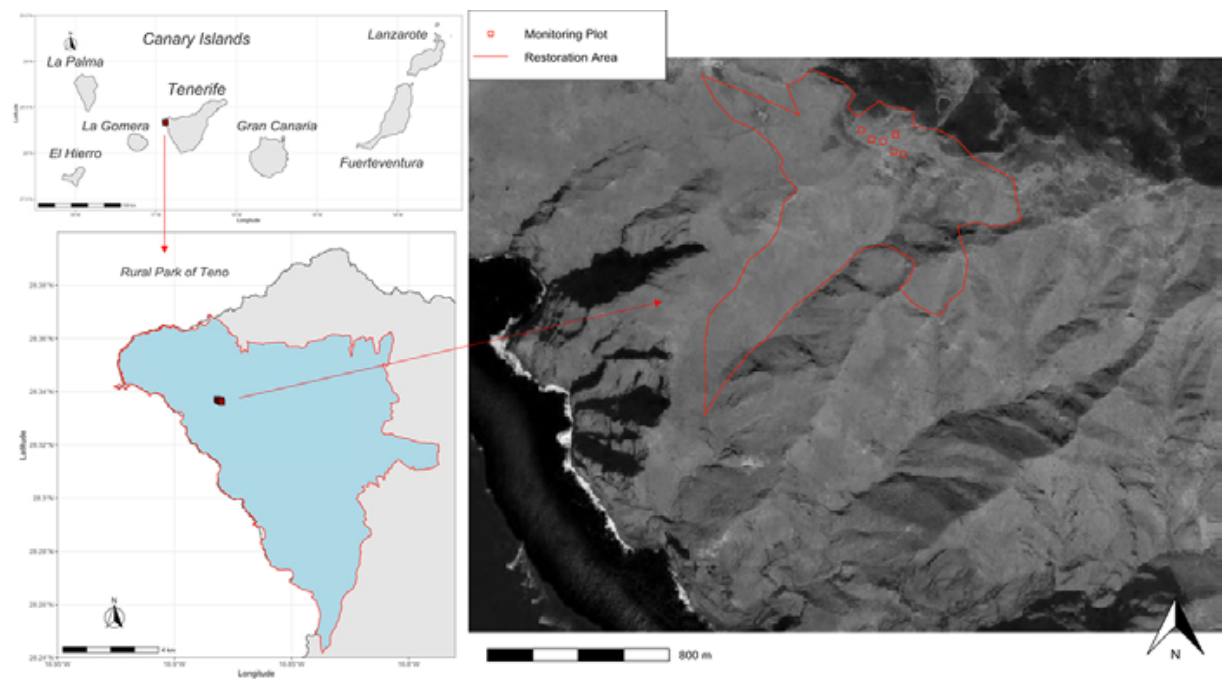

Figure 3. Geographical location of the restoration area and the monitoring plots (from east to west namely A, B, C, D, E and F) within the Rural Park of Teno (delimited in blue), in the north-western part of Tenerife, Canary Islands.

\section{STUDY SITE AND THE RESTORATION PROJECT IMPLEMENTATION}

The study was conducted in the Siete Fuentes farm (57 ha and with an elevational range of 400-950 m), a publicly owned area located in the Barranco de Taburco de Adentro, within the Teno Rural Park protection area, part of the Teno massif located in the north-west extreme of Tenerife, Canary Islands (figure 3). Prior to the restoration the area was used by some goat herds involved in the local production of goat's cheese. Later, the land was bought by the Cabildo with European funds and the goat keepers were invited to use other public owned land in nearby barrancos, so that the restoration project was not threatened.

The Teno massif emerged from the sea ca. 6.2-5.6 Ma Ma, being for most of its history an independent island. It was joined with the other massifs to form the present island of Tenerife during an important volcanic cycle around 1-2 Ma (Goillou et al. 2004). The old age and isolation of the Teno massif, in conjunction with the distinctive morphology of the deeply-dissected landscape, has allowed the evolution of a unique natural heritage. The thermophilous woodland in Teno was potentially situated in the windward slope between 250 and $550 \mathrm{~m}$ a.s.l and in the leeward between 300 and $800 \mathrm{~m}$ a.s.l. (Otto et al. 2012). There is an ideal climate and a suitable soil for agriculture, that are the key reasons why the area has historically been exploited and was largely converted to agricultural use (pastoral and arable). Prior to human arrival, it is believed that the restoration area would have been covered by a woodland dominated by Juniperus turbinata ssp. canariensis and Olea cerasiformis. 
The area of the Siete Fuentes farm was planted with saplings grown in the nursery of "La Tahonilla" (Cabildo Insular de Tenerife, La Laguna), from seeds collected within the closest populations of the species located in a triangle delimited by Icod, to the Northeast, Guía de Isora to the Southeast and Punta de Teno, to avoid genetic dilution when putting them in contact with individuals of different genetic origins (in practice it is possible that a few juniper used in the lower part of the farm were, in error, sourced from Anaga; JMFP pers. observ.). The seedlings obtained were kept under shading structures for a couple of months, until they reached a size of $10-15 \mathrm{~cm}$. Then, they were exposed to direct sunlight, and since the moment of the beginning of the hardening stage coincides with the summer, a shading mesh was placed over them, until the arrival of the least sunny weather. The plants that had survived were prepared to be transported and planted out. Between March 2006 and January 2008, three different phases of planting were undertaken. Approximately $20 \%$ of the holes were made by manual drilling, digging a $40 \mathrm{~cm}$ deep pot, while $80 \%$ were made with a backhoe machine, which due to its special locomotion technique minimizes the effect on the soil and existing plants, paying attention to avoid paths and stony areas with no soil. Subsequently, a single irrigation of about 30-40 liters of water per hole was performed to facilitate the initial establishment of saplings. For this, it was necessary to have a truck with four-wheel drive and at least 400 meters of hose to provide access to all points of the area.

\section{SAMPLING}

In order to continue evaluating the success of the restoration, we focused our monitoring measure at species level, which is considered the most direct way to understand the population response (Block et al. 2001). With that aim, in 2014 we placed six permanent plots $(25 \mathrm{~m} \times 25 \mathrm{~m}, \mathrm{~A}, \mathrm{~B}, \mathrm{C}, \mathrm{D}, \mathrm{E}, \mathrm{F})$ distributed in the upper part (around 800 to $900 \mathrm{~m}$ a.s.l.) of the restoration area. Seedlings have been monitored every March since then (with the exception of 2020) and the data analysed here span 2014-2019.

The monitoring project was set up with both an educational goal (providing students with direct experience of the challenges involved in such exercises and guiding them towards best practice) and the goal of contributing quantitative data on the progress of the restoration experiment. The recording is undertaken in a single afternoon, following a set of written protocols. Each year, a group of 4 to 6 students were assigned to record one of the six plots, overseen by experienced staff members (among them JMFP and RJW). Inevitably, this approach involves a considerable amount of measurement error and so notwithstanding efforts taken to minimize these errors and to correct mistakes made in previous years, the data are likely to feature minor inaccuracies. One particular area of difficulty is the recording of the stem basal diameter, in which errors arise due to changes in the amount of soil and leaf litter surrounding the base of the plant, which in turn lead to changes from year to year in the number of stems recorded and some unlikely gains and losses in basal diameter. Height and canopy diameter measurements, which are taken 
directly with tapes, are more likely to be reliable. Losses in height do sometimes occur due to plants tilting over. This occurred for two main reasons: (1) the plants were originally protected from browsing by stray goats or by rabbits through the installation of cylindrical wire cages during planting. These cages were removed c. 2014 (although some were missed and were then removed in a subsequent sampling year); (2) the site is exposed and windy and without the protection of the cages some plants have been blown over from their original upright position as they have grown. Hence, negative height changes are consistent with field observation. We therefore pay more attention to height and canopy extent than basal diameter measurements.

In each plot, every individual of the eight planted species was tagged, spatially located with $\mathrm{x}-\mathrm{y}$ coordinates (allowing us to produce maps of the individual plants) and measured. In order to describe the annual size increase, we measured height $(\mathrm{cm})$, maximum and orthogonal crown diameters $(\mathrm{cm})$ and stem diameter $(\mathrm{cm})$ immediately above the ground for each plant.

To understand the changes in survival and living stages, a 5-point ordinal vitality index was recorded according to the percentage of damaged or lost leaves observed $(1<25 \%, 2=25-50 \%, 3=50-75 \%, 4>75 \%$ and $5=$ dead individual). Particular attention was paid to Hypericum and Pistacia, in order not to confound leaf-less with dead stages, because both are deciduous species. We also noted the presence of flowers or/and fruits as evidence of reproductive effort.

\section{STATISTICAL ANALYSIS}

The data were analyzed with Microsoft Excel and R (R Core Team, 2020). The vitality, the phenology and the initial and last year growth traits were analyzed per species. In order to understand if the response traits varied significantly among the species in the initial (2014) and last monitored year (2019) a comparison of the mean values was done through a Kruskal-Wallis test for non-parametric data with R function "kruskal.wallis()", followed by a Mann-Whitney U test with Bonferroni correction, with R function "pairwise.wilcox.test()" (Elzinga, 2019). To test for any local variability in growth performance, this analysis was done also to check for difference among monitoring plots for the two dominant species (i.e. Juniperus turbinata ssp. canariensis and Olea cerasiformis) both in initial and final monitoring stage (2014-2019). We applied the Wilcoxon signed rank test with the option for paired samples to test the temporal trend variation (2014-2019) for each species. The comparison letters obtained from the $\mathrm{p}$. values were printed with $\mathrm{R}$ packages "rcompanion" (Mangiafico, 2020) and "multcompView" (Graves, 2015). 
TABLE 1. SURVIVAL AND MORTALITY FROM 2014 TO 2019 WITHIN THE SIX PLOTS

(EACH OF $25 \mathrm{M} \times 25 \mathrm{M}$ ) IN THE SIETE FUENTES SITE (TENO, TENERIFE) OF THE

PLANTED INDIVIDUALS OF EIGHT SPECIES (N TOT = NUMBER OF INDIVIDUALS IN 2014, INCLUDING LIVE AND DEAD PLANTS THAT WERE SECURELY IDENTIFIED TO SPECIES)

\begin{tabular}{|c|c|c|c|c|c|}
\hline Species & $\mathrm{N}$ тот & $\begin{array}{l}\text { Total Live } \\
\text { IN } 2014\end{array}$ & $\begin{array}{l}\text { SuRVIVING } \\
\text { IN } 2019\end{array}$ & $\begin{array}{l}\text { DIED BETWEEN } \\
2014 \text { AND } 2019\end{array}$ & \% MORTALITY \\
\hline Gymnosporia cassinoides & 5 & 5 & 4 & 1 & 20 \\
\hline Heberdenia excelsa & 15 & 15 & 9 & 6 & 40 \\
\hline Hypericum canariense & 54 & 52 & 50 & 2 & 3.85 \\
\hline Jasminum odoratissimum & 37 & 37 & 35 & 2 & 5.41 \\
\hline J. turbinata ssp. canariensis & 58 & 52 & 50 & 2 & 3.85 \\
\hline Olea cerasiformis & 36 & 36 & 34 & 2 & 5.56 \\
\hline Pistacia atlantica & 2 & 2 & 2 & 0 & 0 \\
\hline Visnea mocanera & 8 & 8 & 8 & 0 & 0 \\
\hline All & 215 & 207 & 192 & 15 & 7.25 \\
\hline
\end{tabular}

\section{RESULTS}

\section{Mortality}

In the six study plots, there were 207 surviving plants in 2014, and 192 in 2019 (a mean of 32 per plot). This equates to a density in 2019 of 512 plants hec$\operatorname{tare}^{-1}$, suggesting a mortality of approximately $59 \%$ compared to the initial estimated plantation density of 1237 plants ha ${ }^{-1}$ (Fernández-Palacios et al. 2008). These estimates are broadly consistent with an initial monitoring exercise that was carried out in autumn of 2006, 2007, 2008 and in spring of 2007, 2008, which reported initial survival rates of around 50\%. Between 2014 and 2019 around $7 \%$ of the plants recorded as alive in 2014 died (table 1). Of the five species with a minimum of 10 individuals in 2014, four had mortality rates of 3-6\%, while Heberdenia excelsa lost 6 of 15 individuals, a mortality rate of $40 \%$ and accounting for over a third of the total mortality. Across all species an increase of $5 \%$ in the number of individuals of the highest vitality classes (1-2) was observed between 2014 and 2019 (when it stood at $80 \%$ ).

\section{Phenology}

In 2019, across all species and sites, we recorded 57 plants producing flowers and fruits, which corresponds to $30 \%$ of the surviving individuals showing evidence of reproductive effort, up from c. $18 \%$ in 2014 . While only one juniper was observed to have cones in 2017, three Juniperus individuals were observed with 


\begin{tabular}{|c|c|c|c|c|c|c|}
\hline \multicolumn{7}{|c|}{$\begin{array}{l}\text { TABLE 2. MEAN AND STANDARD DEVIATION (SD) OF HEIGHT, CROWN AREA AND STEM } \\
\text { DIAMETER OF SURVIVING INDIVIDUALS IN THE SIX PLOTS (COMBINED) AS OF } 2014 \\
\text { AND } 2019 \text { (FOR N VALUES SEE TABLE 1). WE EXCLUDED G. cassinoides AND } \\
\text { P. atlantica DUE TO LOW NUMBER OF LIVING INDIVIDUALS. } \\
\text { (HEIGHT }=\mathrm{cm} \text {, CROWN AREA }=\mathrm{m}^{2} \text {, STEM DIAMETER }=\mathrm{mm} \text { ). }\end{array}$} \\
\hline & \multicolumn{2}{|c|}{ Height } & \multicolumn{2}{|c|}{ Crown Area } & \multicolumn{2}{|c|}{ Stem Diameter } \\
\hline Species & 2014 & 2019 & 2014 & 2019 & 2014 & 2019 \\
\hline Heberdenia excelsa & $37.42(15.71)$ & 33.67 (17.07) & $.02)$ & 0.04 & $12.54(4.27)$ & 25.87 \\
\hline $\begin{array}{l}\text { Hypericum } \\
\text { canariense }\end{array}$ & $78.07(21.61)$ & $88.1(32.37)$ & $0.40(0.27)$ & $0.93(0.81)$ & $17.50(8.06)$ & $27.19(15.58)$ \\
\hline $\begin{array}{l}\text { Jasminum } \\
\text { odoratissimum }\end{array}$ & $71.02(21.58)$ & $91.59(24.7)$ & $0.20(0.16)$ & $0.7(0.6)$ & $21.54(10.29)$ & $31.58(24.93)$ \\
\hline $\begin{array}{l}\text { Juniperus turbinata } \\
\text { ssp. canariensis }\end{array}$ & $75.64(28.74)$ & $108.3(40.01)$ & $0.37(0.28)$ & $1.94(1.29)$ & $27.14(13.65)$ & $64.24(13.05)$ \\
\hline Olea cerasiformis & 87.64 (22.57) & $140.85(35.78)$ & $0.53(0.38)$ & $2.64(1.26)$ & 39.74 (18.43) & $82.86(30.27)$ \\
\hline Visnea mocanera & $50.33(18.28)$ & $99.38(52.05)$ & $0.10(0.08)$ & $0.66(0.62)$ & $16.08(5.95)$ & $34.48(17.56)$ \\
\hline
\end{tabular}

cones in 2018 and in 2019. Many Olea, Hypericum and Jasminum individuals bore fruits and flowers. The number of individuals flowering or fruiting per species, across all six sites, were as follows: Olea cerasiformis 2014, 0; 2015, 0; 2016 1; 2017 8; 2018, 1, and 2019, 3; Hypericum canariense 2014, 20; 2015, 8; 2016, 26; 2017, 23; 2018, 7, and 2019, 17; Jasminum odoratissimum 2014, 18; 2015, 28; 2016, 23; 2017, 31; 2018, 31, and 2019, 32; Juniperus turbinata ssp. canariensis 2014, 0; 2015, 1; 2016, 1; 2017, 2; 2018, 3, and 2019, 3. One individual of Gymnosporia cassinoides started fruiting in 2018 and one individual of Visnea mocanera was first observed flowering in 2019. There was no evidence of flowering or fruiting in the surviving individuals of Heberdenia excelsa.

\section{Growth TRAITS AND RATES}

The size (Height, Crown Area and Stem Diameter) attained by 2014 and 2019 by surviving individuals varied significantly between species (Kruskal-Wallis sum rank test, $\mathrm{p}<0.001$ for each trait for both 2014 and 2019). The mean values and SD for each variable are reported in table 2. Heberdenia excelsa was found to be the most different from the other species for each attribute. Olea individuals are on average the tallest, the largest in crown area and in stem size, followed by Juniperus (tables 2, 3). All six species of $\mathrm{n}>8$ individuals show significant growth increments over the sampling period except Heberdenia excelsa (figure 4).

We provide more detailed plot-by-plot analyses of our two structural species O. cerasiformis and J. turbinata ssp. canariensis, both of which have relatively large representation in the study. The Kruskal-Wallis test showed significant $(\mathrm{p}<0.001)$ variation among the plots only for the juniper, both in the initial and final stage of 


\begin{tabular}{|c|c|c|c|c|c|c|}
\hline \multicolumn{7}{|c|}{$\begin{array}{l}\text { TABLE 3. MANN-WHITNEY U TEST FOR THE SIZE VARIABLES FOR THE INITIAL } \\
\text { MONITORING YEAR (2014) AND THE FINAL MONITORING YEAR (2019), VALUES } \\
\text { SHARING A LETTER ARE NOT SIGNIFICANTLY DIFFERENT FOR EACH YEAR } \\
(\mathrm{P}<=0.05 \text { WITH BONFERRONI CORRECTION) }\end{array}$} \\
\hline & \multicolumn{2}{|c|}{ Height } & \multicolumn{2}{|c|}{ Crown Area } & \multicolumn{2}{|c|}{ Stem Diameter } \\
\hline Species & 2014 & 2019 & 2014 & 2019 & 2014 & 2019 \\
\hline Heberdenia excelsa & a & a & a & a & a & a \\
\hline Hypericum canariense & bc & b & bc & $\mathrm{b}$ & $a b$ & a \\
\hline Jasminum odoratissimum & $\mathrm{bc}$ & $\mathrm{b}$ & d & $b$ & bc & a \\
\hline Juniperus turbinata ssp. canariensis & bc & b & bd & c & c & $\mathrm{bc}$ \\
\hline Olea cerasiformis & b & c & c & d & d & b \\
\hline Visnea mocanera & $\mathrm{ac}$ & $a b c$ & ad & bc & $a b c$ & $\mathrm{ac}$ \\
\hline
\end{tabular}

TABLE 4. KRUSKAL-WALLIS RANK SUM TEST COMPARING EACH SIZE VARIABLE PER YEAR AGAINST PLOT FOR THE TWO DOMINANT SPECIES (PLOT B WAS EXCLUDED FOR Olea Cerasiformis BECAUSE IT HAS ONLY 1 INDIVIDUAL)

\begin{tabular}{|c|c|c|c|c|c|c|c|c|c|c|c|c|c|}
\hline \multirow[b]{3}{*}{ Species } & & \multicolumn{4}{|c|}{ Height $\sim$ Plot } & \multicolumn{4}{|c|}{ Crown area - Plot } & \multicolumn{4}{|c|}{ Stem diameter $\sim$ Plot } \\
\hline & & \multicolumn{2}{|c|}{2014} & \multicolumn{2}{|c|}{2019} & \multicolumn{2}{|c|}{2014} & \multicolumn{2}{|c|}{2019} & \multicolumn{2}{|c|}{2014} & \multicolumn{2}{|c|}{2019} \\
\hline & $\mathrm{df}$ & $\mathrm{p}$ & $x^{2}$ & $\mathrm{p}$ & $\chi^{2}$ & $\mathrm{p}$ & $\chi^{2}$ & $\mathrm{p}$ & $\chi^{2}$ & $\mathrm{p}$ & $\chi^{2}$ & $\mathrm{p}$ & $x^{2}$ \\
\hline
\end{tabular}

Juniperus

turbinata ssp. $5<0.001 \quad 21.801<0.001 \quad 24.642<0.001 \quad 26.127<0.001 \quad 24.714 \quad 0.002 \quad 19.347<0.001 \quad 26.214$ canariensis

\begin{tabular}{llllllllllllll}
\hline $\begin{array}{l}\text { Olea } \\
\text { cerasiformis }\end{array}$ & 4 & 0.845 & 1.393 & 0.42 & 3.896 & 0.461 & 3.615 & 0.389 & 4.126 & 0.17 & 6.476 & 0.46 & 3.619 \\
\hline
\end{tabular}

TABLE 5. MANN-WHITNEY U TEST FOR THE SIZE VARIABLES FOR THE INITIAL MONITORING YEAR (2014) AND THE FINAL MONITORING YEAR (2019) AMONG FIXED-MONITORING PLOTS (A TO F), VALUES SHARING A LETTER ARE NOT SIGNIFICANTLY DIFFERENT ( $\mathrm{P}<=0.05$ WITH BONFERRONI CORRECTION) FOR THE DOMINANT SPECIES Juniperus turbinata ssp. Canariensis

\begin{tabular}{|c|c|c|c|c|c|c|c|}
\hline \multirow[b]{2}{*}{ Species } & \multirow[b]{2}{*}{ PLOT } & \multicolumn{2}{|c|}{ Height } & \multicolumn{2}{|c|}{ Crown Area } & \multicolumn{2}{|c|}{ Stem Diameter } \\
\hline & & 2014 & 2019 & 2014 & 2019 & 2014 & 2019 \\
\hline \multirow[t]{6}{*}{$\begin{array}{l}\text { Juniperus turbinata ssp. } \\
\text { canariensis }\end{array}$} & A & $a b$ & $a b$ & $\mathrm{a}$ & a & $a b$ & $a b$ \\
\hline & B & a & $\mathrm{a}$ & $\mathrm{bc}$ & $a b$ & $a b$ & $a b$ \\
\hline & $\mathrm{C}$ & $\mathrm{b}$ & $\mathrm{b}$ & $\mathrm{ab}$ & $\mathrm{a}$ & $\mathrm{a}$ & $\mathrm{a}$ \\
\hline & $\mathrm{D}$ & $a b$ & $\mathrm{ab}$ & $\mathrm{a}$ & a & $a b$ & $a b$ \\
\hline & $\mathrm{E}$ & $\mathrm{a}$ & $\mathrm{a}$ & c & $\mathrm{b}$ & b & $\mathrm{b}$ \\
\hline & $\mathrm{F}$ & $a b$ & $a b$ & $a b c$ & $a b$ & $a b$ & $a b$ \\
\hline
\end{tabular}

the monitoring (table 4). The juniper shows considerable between-plot variation in performance for the height in plots B and $\mathrm{E}$ for both the initial and final stage of the monitoring (table 5). Even within plots, there appears to be some variation in 

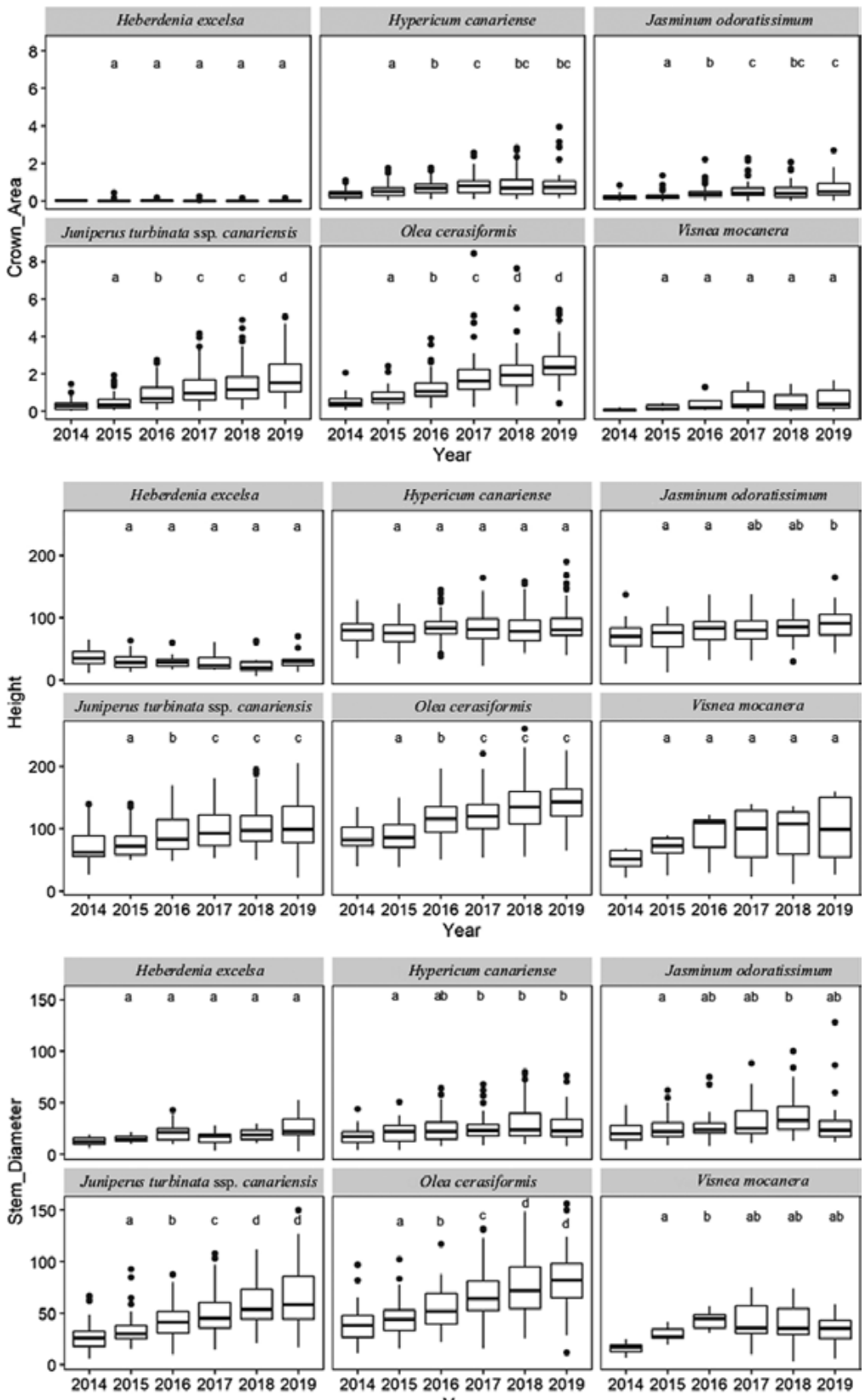

Figure 4. Plots showing variation in height $(\mathrm{cm})$, crown area $\left(\mathrm{m}^{2}\right)$ and stem diameter $(\mathrm{mm})$ for six different species across time (2014 to 2019). Values sharing a letter are not significantly different after pairwise Mann-Whitney comparison test along the years ( $\mathrm{p}<=0.05$ with Bonferroni correction). (middle bar $=$ median or $50^{\text {th }}$ percentiles, box limits $=25 \%$ and $75 \%\left(25^{\text {th }}\right.$ and $75^{\text {th }}$ percentile), vertical lines $=$ minimum and maximum, dots $=$ outliers $)$ 

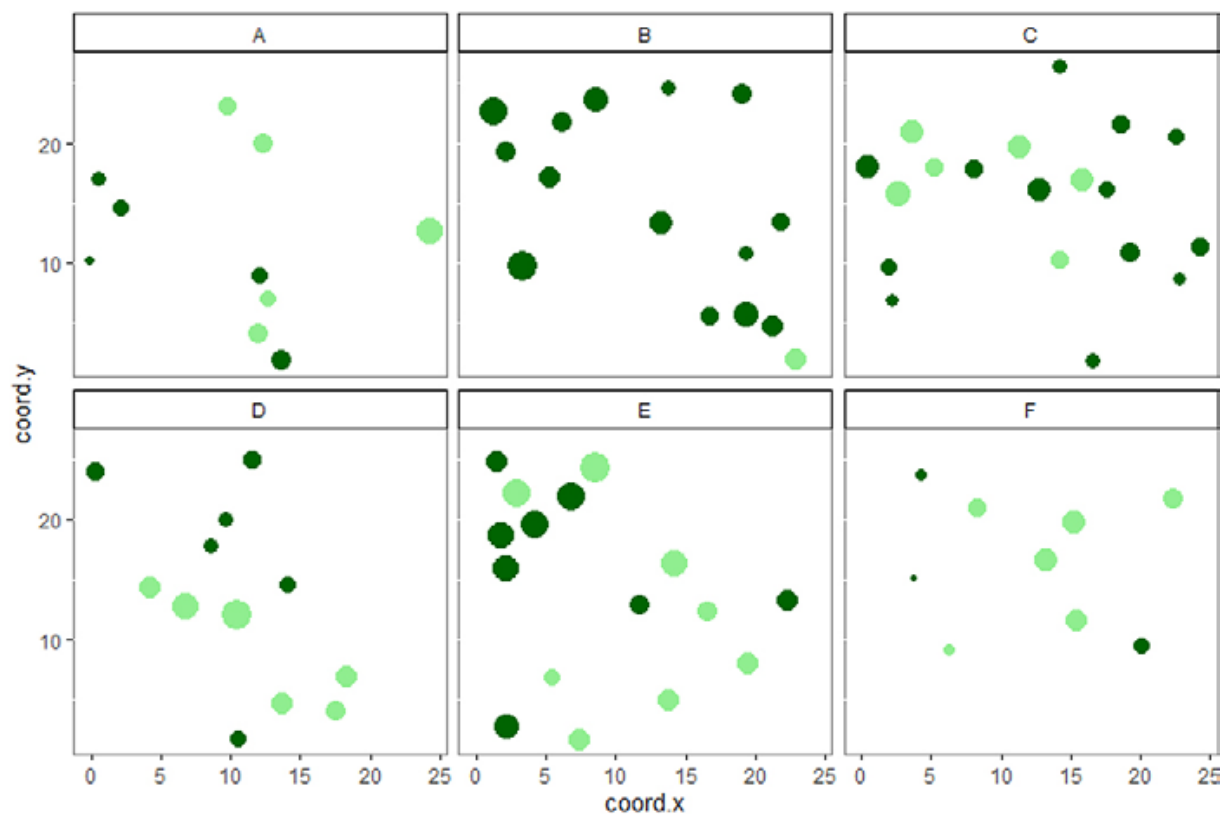

Figure 5. Maps of the six permanent $25 \mathrm{~m} \times 25 \mathrm{~m}$ plots: A and $\mathrm{F}$ show little growth compared to the other plots. Dark green corresponds to junipers while light-green to wild olive while the size of the circle corresponds to the crown area $\left(\mathrm{m}^{2}\right)$ for each surviving juniper and wild olive in 2019.

growth of these two species in response to local topography and variations in soil depth and shelter, although it should be understood that sample sizes are rather small for format testing (see figure 5).

\section{DISCUSSION}

Monitoring is important for evaluating the success of restoration experiments (Michener, 1997, Ruiz-Jaén and Aide, 2005, Herrick et al. 2006). The monitoring should be conducted over a sufficiently long time to ensure that the populations have adjusted to time-dependent changes resulting from restoration treatments and also to incorporate the range of environmental conditions allowing for valid estimates of process variation (Block et al. 2001). However, for this particular project there were no funds specifically allocated to continuing the monitoring activities, a component of such projects described as critical by Lindenmayer and Likens (2010) policy-makers and managers. (By taking advantage of an educational opportunity (the annual visits of a field course of MSc students), we were able to implement a simple monitoring project extending over a number of years, and which we hope to be able to continue. 
Overall, we have estimated the total mortality since planting to be around $59 \%$, most of which happened very shortly after planting. This fairly high mortality may reflect that due to practical constraints, the planting out of many of the seedlings had to be done at the start of the driest part of the year. It should be noted, however, that this particular estimate is rather crude, being based on sites located in the upper part of the site and on a general estimate of planting density across the whole site, as we only began tracking the fate of plants in the six plots in 2014, some six years after the planting was completed. In another thermophilous restoration project carried out in the neighboring island of Gran Canaria (LIFE+ Guguy LIFE12 NAT/ES/000286, 2013), where planting was completed in 2014, there was a reported $42.2 \%$ initial mortality rate (Gesplan, 2019), not far below the c. 50\% initial reported rate in the Teno study c. 2008 (above). There were some differences between the two studies, which shared just three species in common (Juniperus turbinata ssp. canariensis, Olea cerasiformis and Pistacia atlantica), but these data indicate broadly similar levels of early mortality.

Our monitoring of the Juniper woodland restoration project in Teno Rural Park in Tenerife has shown that between 2014 and 2019, now a little over a decade on from the planting, the plantation can be considered reasonably well established, although most plants remain small and the cover provided by the plantation species remains limited. During this time, survival has been good and growth steady for each of the species in the study plots, with the exception of Heberdenia excelsa. Cubas et al. (2019) demonstrate that endemic plant species are often more vulnerable to browsing damage from introduced herbivores than non-endemic plant species in oceanic islands. In the case of Heberdenia excelsa, a Macaronesian endemic species in the family Primulaceae, we consider rabbits to be the principal cause of the herbivory damage that has limited their growth and indeed caused plant shrinkage and mortality. That has happened especially after the retrieval of the protectors, which took place mostly in 2014 and 2015, paradoxically to avoid damage to the plants from chaffing against the wire as they grew through the gaps and to permit access for measurements. Observations of nibbled stems and characteristic angled cut marks, combined with the incidence of rabbit droppings in the site, support this inference. For this species, at least in open sites favored by rabbits, it appears that some form of browsing protector shield is necessary for the plants to survive and reach adulthood. Removal of the wire protectors was necessary to conduct the monitoring and because plants were being damaged by the wire, but it has had a mixed outcome. To avoid that, better designed protective shields are needed.

In general, the good survival and growth of both structural dominant species, and especially of Olea, suggests that there is a strong prospect of both maturing to form, at least in the upper parts of the restored area, the largest component of the woodland, attaining at least one element of the key goals of the restoration project. Individuals of most species in the restoration remain far below their potential mature size, especially so for Olea and Juniperus, which can potentially reach heights 10-12 $\mathrm{m}$ of and 5-8 m, respectively. Even specimens of Hypericum canariense, for which a mean height of $88 \mathrm{~cm}$ was obtained, have potential to grow 2 to $3 \mathrm{~m}$ in height in the right conditions, but have yet to do so within the site. The variation in growth 
and survival recorded within our plots is probably a function of local topographic controls on soil depth, moisture and exposure to strong winds and drought. This points to the likelihood that this site will show rather slow and patchy development of thermophilous woodland in the coming years, with some variation in composition developing across the site, resulting both from intentional variation in initial planting but also from varying species performance. In these upper reaches of the site, the conditions seem to be particularly suited to the wild olive, mixed also with clumps of juniper.

Another key feature of such a restoration project is the capacity of the replanted stands to regenerate themselves and to provide a habitat for the spontaneous appearance of additional native species through seed dispersal into the newly developing woodland habitat. Here there are some encouraging signs, in that individuals of six of our study species were showing evidence of reproductive effort (fruits or flowers). In addition, in 2018 and 2019, around 45 seedlings (in total) of two of the study species were observed to have established within the study sites: Jasminum in three of the plots (C, D and F) and Hypericum in one plot (E). They are quite hard to find given the ground vegetation cover is quite dense in March and it is more than likely that more thorough investigation of the sites would have revealed rather more seedlings of these particular species.

Providing that the restoration area is allowed to continue undisturbed and even without further intervention, our data support the hope that in time, the restoration project will give rise to a new patch of thermophilous woodland within the Barranco de Taburco de Adentro. Further management intervention to provide protection from grazing for particular species, especially for Heberdenia excelsa, modest interventions to control re-invasion of more open parts of the site by the exotic invasive species Opuntia maxima and Agave americana, and an extension of the monitoring work to examine lower elevations within the restoration area (following Otto et al. 2012) would each be worthwhile steps, which we recommend be considered. We close by expressing the hope that the thermophilous woodland restoration project in Teno may serve as a model system for improving our understanding of the dynamics of this greatly endangered ecosystem type and as an inspiration for further efforts to restore this ecosystem type in other locations. 


\section{REFERENCES}

Adams, R.P., Nguyen, S. and Achak, N. (2006). Geographic variation in Juniperus phoenicea from the Canary Islands, Morocco and Spain, based on RAPDS analysis. Phytologia 88: 270-278.

Bello-Rodríguez, V., García, C., del Arco, M.J., Hernández-Hernández, R. and GonzálezMancebo, J.M. (2016). Spatial dynamics of expanding fragmented thermophilous forests on a Macaronesian island. Forest Ecology and Management, 379, 165-172. doi:10.1016/j. foreco.2016.08.015.

Block, W.M., Ganey, J.L., Ward, J.P., White, G.C. and Franklin, A.B. (2001). Design and Implementation of Monitoring Studies to Evaluate the Success of Ecological Restoration on Wildlife. Restoration Ecology, 9(3), 293-303. doi:10.1046/j.1526-100x.2001.009003293.x.

Burton, P.J. (2014). Considerations for Monitoring and Evaluating Forest Restoration. Journal of Sustainable Forestry, 33(SUP1), 37-41. doi:10.1080/10549811.2014.884001.

Cubas, J., Irl, S.D.H., Villafuerte, R., Bello-Rodríguez, V., Rodríguez-Luengo, J.L., Del Arco, M., Martín-Esquivel, J.L. and GónZalez-Mancebo, J.M. (2019). Endemic plant species are more palatable to introduced herbivores than non-endemics. Proceedings of the Royal Society B: Biological Sciences, 286.

Del Arco Aguilar, M.J., González-González, R., Garzón-Machado, V. and PizarroHernández, B. (2010). Actual and potential natural vegetation on the Canary Islands and its conservation status. Biodiversity and Conservation, 19(11), 3089-3140. doi:10.1007/ s10531-010-9881-2.

Elzinga, Caryl, L., Salzer, Daniel W. and Willoughby, John W. (2019). "Measuring and Monitoring Plant Populations.” U.S. Bureau of Land Management Papers. 41.

Fernández-Palacios, J.M., Otto, R., Domingo Delgado, J., Arévalo, J.D., Naranjo, A., González Artiles, F., ..., Barone, R. (2008). Los bosques termófilos de Canarias: Proyecto LIFE04/NAT/ES/000064. Cabildo Insular de Tenerife, 1-202.

Fernández-Palacios, J.M., Otto, R., Tosco, R.B., Cigala, A.N., García, J.D.D., Sierra, J.R.A. and Pérez, R.S.A. (2020). Los sabinares canarios. Rincones del Atlántico, (10), 138-155.

Forsyth, D.M., Scroggie, M.P., Arthur, A.D., Lindeman, M., Ramsey, D.S.L., McPhee, S.R., ... STUART, I.G. (2015). Density-dependent effects of a widespread invasive herbivore on tree survival and biomass during reforestation. Ecosphere, 6(4), 1-17. doi:10.1890/ES14-00453.1.

Gesplan (2019). Acción D.1.: Evaluación de la implementación de las acciones de restauración y mejora del hábitat. Proyecto LIFE+ Guguy (LIFE12 NAT/ES/000286).

Graves, S., Piepho, H-P. and Selzer, L. with help from Sundar Dorai-Raj (2015). multcompView: Visualizations of Paired Comparisons. R package version 0.1-7. https:/CRAN.R-project. org/package $=$ multcompView.

Guillou, H., Carracedo, J.C., Paris, R. and Torrado, F.J.P. (2004). Implications for the early shield-stage evolution of Tenerife from K/Ar ages and magnetic stratigraphy. Earth and Planetary Science Letters, 222(2), 599-614.

Hall, F.C. (2002). Photo Point Monitoring Handbook: Field Procedures (Part A) and Concepts and Analysis (Part B). United States Department of AgricultureForest Services Pacific Northwest Research Station. doi:10.1016/j.ecoleng.2004.06.003. 
Herrick, J.E., Schuman, G.E. and Rango, A. (2006). Monitoring ecological processes for restoration projects. Journal for Nature Conservation, 14(3-4), 161-171. doi:10.1016/j. jnc.2006.05.001.

Lindenmayer, D.B. and Likens, G.E. (2010). The science and application of ecological monitoring. Biological Conservation, 143(6), 1317-1328. doi:10.1016/j.biocon.2010.02.013.

Mangiafico, S. (2020). rcompanion: Functions to Support Extension Education Program Evaluation. $\mathrm{R}$ package version 2.3.25. https://CRAN.R-project.org/package=rcompanion.

Otto, R., Barone, R., Delgado, J.D., Arévalo, J. R., Garzón-Machado, V., CabreraRodríguez, F., and Fernández-Palacios, J.M. (2012). Diversity and distribution of the last remnants of endemic juniper woodlands on Tenerife, Canary Islands. Biodiversity and Conservation, 21(7), 1811-1834. doi:10.1007/s10531-012-0278-2.

Otto, R., Krüsi, B.O., Delgado, J.D., Fernández-Palacios, J.M., García-Del-Rey, E. and ArÉvalo, J.R. (2010). Regeneration niche of the Canarian juniper: the role of adults, shrubs and environmental conditions. Annals of Forest Science, 67(7), 709-709. doi:10.1051/ forest $/ 2010034$.

R Core Team (2020). R: A language and environment for statistical computing. R Foundation for Statistical Computing, Vienna, Austria. URL https:/www.R-project.org/.

Ruiz-JAÉn, M.C. and Aide, T.M. (2005). Restoration success: how is it being measured? Restoration Ecology, 13(3), 569-577.

Schultz, C.A., Jedd, T. and BeAm, R.D. (2012). The collaborative forest landscape restoration program: A history and overview of the first projects. Journal of Forestry, 110(7), 381-391. doi:10.5849/jof.11-082. 
